http://dx.doi.org/10.18359/ravi.1404

\title{
Mapping digital competences of modern languages students ${ }^{1}$
}

\author{
Olga Camila Hernández Morales ${ }^{2}$, Helman Alirio Amaya Espinosa ${ }^{3}$, Lina Fernanda Rodríguez Duque ${ }^{4}$, \\ Erika Eliana Gutiérrez Barrera ${ }^{5}$ \& Viviana Suárez Casas $^{6}$
}

Universidad ECCI, Colombia

Recibido, octubre 30 de 2015

Concepto evaluación, febrero 09 de 2016

Aceptado, febrero 15 de 2016
Referencia: Hernández Morales, O.; Amaya Espinosa, H.; Rodríguez Duque, L.; Gutiérrez Barrera, E.; Suarez Casas, V. (2016). "Mapping digital competences of modern languages students". Revista Academia y Virtualidad, 9, (1), 89-104

\begin{abstract}
During recent years, digital competence has become a key concept in the discussion of which skills and understanding people should have in the knowledge society. This paper offers the results of a research project that set out to describe digital natives' perceptions of their ICT competences. A mixed case study approach was used, applying a survey to collect data based on three proposed dimensions: instrumental, socio-communicative, and axiological. Among the main findings, it was possible to describe the way digital natives interact with ICT tools, and the tendencies in their use for social and communicative purposes.
\end{abstract}

Keywords: digital natives, digital competence, instrumental dimension, socio-communicative dimension, axiological dimension.

\footnotetext{
1 Artículo de investigación científica y tecnológica como resultado del proyecto de investigación "Serious game como estrategia en el desarrollo de las competencias interculturales y comunicativas en la sociedad digital del conocimiento". Financiado por la Universidad ECCI (Convocatoria Interna de proyectos de investigación 2015) Referencia IN-015
}

2 (2014) Magster in Education, Universidad Pedagógica Nacional. (2011) Bachelor in Modern Languages, Universidad Distrital Francisco José de Caldas. (2013-current) Research specialist and professor. R\&D Vice-rectory Universidad ECCI. (2010-current) Museum Educator at Museo Nacional de Colombia. E-mail: ohernandezm@ecci.edu.co

3 (2015) Magister Medical Physics, Universidad Nacional de Colombia. (2011) Bachelor in pharmacy, Universidad Nacional de Colombia. (2014-current) Professor. Basic sciences department ECCI. E-mail: hamayae@ecci.edu.co

(2013) Escuela Colombiana de Carreras Industriales, Professional Technician in Modern Languages. (current) Escuela Colombiana de Carreras Industriales, Professional in Modern Languages. Research assistant Intercultural studies seedbed Modern Languages Program at ECCI University. E-mail: linaduke92@hotmail.com

${ }^{4}$ (2013) Escuela Colombiana de Carreras Industriales, Professional Technician in Modern Languages. (current) Escuela Colombiana de Carreras Industriales, Professional in Modern Languages. Research assistant Intercultural studies seedbed Modern Languages Program at ECCI University. E-mail: erikmoongb@hotmail.com

5 (2013) Escuela Colombiana de Carreras Industriales, Professional Technician in Modern Languages. (current) Escuela Colombiana de Carreras Industriales, Professional in Modern Languages. Research assistant Intercultural studies seedbed Modern Languages Program at ECCI University. E-mail: anavi_1516@hotmail.com 


\section{Cartografía de las competencias digitales de estudiantes de lenguas modernas}

\section{Resumen}

Durante los últimos años, la competencia digital se ha convertido en un concepto clave para el análisis del tipo de habilidades y comprensiones que una persona debe tener en la sociedad del conocimiento. Este artículo presenta los resultados de un proyecto de investigación que busca describir las percepciones de los nativos digitales acerca de sus competencias tecnológicas. Para alcanzar el propósito de este artículo se desarrolló un estudio de caso mixto, mediante la aplicación de una encuesta para recopilar datos en tres dimensiones propuestas: dimensión instrumental, dimensión sociocomunicativa y dimensión axiológica. Entre los resultados principales se describe la forma como los nativos digitales interactúan con herramientas tecnológicas, y la tendencia alrededor del uso de la tecnología para efectos sociocomunicativos.

Palabras clave: nativos digitales, competencia digital, dimensión instrumental, dimensión sociocomunicativa, dimensión axiológica.

\section{Cartografia das competências digitais de estudantes de línguas modernas}

\section{Resumo}

Durante os últimos anos, a competência digital tem se convertido num conceito chave para a discussão do tipo de habilidades e compreensões que uma pessoa tem de ter na sociedade do conhecimento. Este artigo apresenta os resultados de um projeto de pesquisa que busca descrever as percepções dos nativos digitais acerca das suas competências tecnológicas. Para atingir o propósito deste artigo desenvolveu-se um estudo de caso misto, mediante a aplicação de uma enquete para coletar dados em três dimensões propostas: dimensão instrumental, dimensão sócio comunicativa e dimensão axiológica. Entre os resultados principais descreve-se o jeito como os nativos digitais interatuam com ferramentas tecnológicas, e a tendência ao redor do uso da tecnologia para efeitos sócio comunicativos.

Palavras chave: nativos digitais, competência digital, dimensão instrumental, dimensão sócio comunicativa, dimensão axiológica. 


\section{Introduction}

Currently the knowledge society demands some key competences to guarantee people adaptation to constant changes. The central notions that guide those competences are related to critical thinking, creativity, initiative taking, problem solving, risk management, decision taking and managing feelings in a constructive manner.

The recommendation of the European Parliament and the Council 2006 recognized eight key competences for Lifelong Learning: communication in the mother tongue; communication in foreign languages; mathematical competence and basic competences in science and technology; digital competence; learning to learn; social and civic competences; entrepreneurship; and cultural awareness and expression (Ferrari, 2013 p. 9)

Indeed digital competence has been confirmed as a relevant priority for the European Commission in more recent policies, actions, and communications, defined as "involving the confident and critical use of Information Society Technology (IST) for work, leisure and communication" (Cinque, 2014, p. 91). In this sense, being able to benefit from digital tools must be one the main objectives that people need to accomplish today; nevertheless, the benefits that people gain may vary widely based on interest, values and opportunities.

According to research, digital usage does not lead to improvement or development of advanced digital competence as such (AlaMutka, 2011). Understanding basic tools and computer applications is only an initial step towards advanced knowledge, skills and attitudes in digital competence. According to Ferrari (2013) the digital competence involves a set of knowledge (cognitive) and attitudes (procedures), required when we are performing a task that is mediated by ICT tools. Among the main characteristics of the digital competence based on the same author we can highlight the development of advanced skills for problem solving, the different ways for managing information, the new means for communicating ideas, creating and sharing contents; and the possibilities for interacting, socializing and building in an autonomous way a digital identity.

On account of the previous ideas mentioned it is possible to identify the importance of the development of the digital competences as a process of empowerment, starting for the recognition of instrumental skills towards socio-communicative and critical personal aptitudes. Finally, a perspective of digital competence should also include cultural background and practices. Accordingly, it is important to bear in mind the changing tools and practices people use in their work, study and daily life.

This article presents the results of the first phase of a research project aimed at designing and implementing a "serious game" to enhance technological understanding through the development of key competences. Serious game is defined by Zyda (2005, p. 26) as "a mental contest, played with a computer in accordance with specific rules, that uses entertainment to further government or corporate training, education, health, public policy, and strategic communication objectives." Accordingly, the research question was, "What are digital natives' perceptions on their digital competences?" The main objective of this phase was characterizing students' perceptions as digital natives, and describing their digital competences and use of technological tools. The study involved a qualitative descriptive study based on a survey applied to a sample of 67 students. The survey was divided in three parts having in mind Area's (2010) proposed dimensions in the learning process mediated by ICT tools: instrumental, socio-communicative, and axiological, according to three proposed dimensions. Results demonstrate the largest frequency of responses corresponding to the social dimension. These results validate the 
hypothesis that students' use of technologies is focused more towards social networks than academic or personal development. Further, findings suggest that participants are only developing skills, not digital competences.

\section{Literature Review}

\section{Digital Competence}

Throughout the last years digital competence has become a key issue in the discussion about which skills people must develop in the knowledge society. Also it is a concept that reflects a political perspective about the necessities for economic competition through new technologies.

In the research context, the concept is still seldom used. We based our study on the European Qualifications Framework recommendation through the Life Long Learning Program (in Grün, G; TritscherArchan, S; Weiß, S, 2009, p. 3) that defines 'competence' as "means the proven ability to use knowledge, skills and personal, social and methodological abilities in work or study situations and in professional and/or personal development." This definition was consider appropriate in the context of this study having in mind the three dimension proposed (instrumental, socio-communicative and axiological), that refers to knowledge on technology, social usage and personal development.

Digital competence is a set of knowledge, skills, attitudes, strategies and awareness required when using ICT and digital media to perfume tasks; solve problems; communicate; manage information; create and share contents and build critical knowledge (European Commission, 2014).

The digital competence is an emerging concept related to the development of technology involving technical skills to use it, abilities to apply technology in different contexts and various activities, and capacity to evaluate in a critical way technology as a member of a digital culture. One of the general perceptions is that digital competence is about essential life skills for all, even labelled as "survival skills in the digital era" (Eshet-Alkalai, 2004) or "vital assets in information society" (van Deursen, 2010).

The relation between competence and skills is defined for the OECD as: "A competency is more than just knowledge and skills. It involves the ability to meet complex demands by drawing on and mobilizing psychosocial resources (including skills and attitudes) in a particular context" (OECD, 2005, p. 4). The latest definitions of digital competence include social, emotional and cultural aspects for understanding and interacting with digital devices. The European Commission (in Punie \& Cabrera, 2006) has defined digital competence as:

[...] involving the confident and critical use of Information Society Technology for work, leisure and communication. Digital competence is grounded on basic skills in ICT, i.e. the use of computers to retrieve, assess, store, produce, present and exchange information, and to communicate and participate in collaborative networks via the Internet.

To characterize the main compounds of the digital competences there has been some initiatives define the necessary competencies for the future; various institutions, consortia and national policy makers have projects aiming to define the competences either in a general sense or for a chosen group, such as teachers or students.

UNESCO (2010) has a project about ICT Competency Standards for Teachers. The competencies consist of four components: Policy and vision, Technology literacy, Knowledge deepening, and Knowledge creation, and each of them, several topics. On the other hand, the International Society for Technology in Education has defined the 
educational technology standards for students (ISTE, 2007). The main competencies are creativity and innovation; communication and collaboration; research and information fluency; critical thinking, problem solving, and decision making; digital citizenship, and technology operations and concepts.

Furthermore, the Assessment and Teaching of 21st Century Skills project (ATC21, 2009) was created by Cisco, Intel and Microsoft and launched 2009 (the project is still going on and the paper referred is a draft). In this project, the focus was in the new ways and methods for assessment and teaching. The skills in the paper (referred as 21 st century skills) were grouped to four main categories listed in Table 1.

Table 1 . The 21 st century skills.

$\begin{array}{llll}\text { Ways of Thinking } & \text { Ways of Working } & \text { Tools for Living } & \text { Living in the world } \\ \begin{array}{l}\text { Creativity and } \\ \text { innovation }\end{array} & \begin{array}{l}\text { Communication, } \\ \text { collaboration }\end{array} & \begin{array}{l}\text { Information } \\ \text { literacy }\end{array} & \text { Citizenship } \\ \begin{array}{l}\text { Critical thinking, } \\ \text { problem solving, } \\ \text { decision making }\end{array} & \text { ICT literacy } & \text { Life and career } \\ \begin{array}{l}\text { Learning to learn, } \\ \text { metacognition }\end{array} & & \begin{array}{l}\text { Personal-social } \\ \text { responsibility }\end{array}\end{array}$

Moreover, Area (2010) stated a proposal to rethink the traditional literacy based on the ICT mediation in the educational context. The necessity of developing competences to codify and de-codify information, demand us skills enhancing in different stages: the first stage is the Instrumental Dimension related to the technical use of technological tools (hardware and software). The second stage or Cognitive Dimension refers to the acquisition of knowledge and skills to search, select, analyze and understand the amount of information available in the net. The third stage related to the Communicative Dimension involves the development of abilities to create contents and share them in the social interaction. Finally, the last stage, the Axiological Dimension, encompasses the achievement of ethical and democratic values for the digital society.

\section{Digital Natives}

Another key concept to build the framework on digital competences is digital natives. The central argument to support the idea of the digital native is that young people born in the last two decades have always been surrounded by, and interacted with, new technologies, which provide them with specific characteristics. According to Prensky, the most essential consequences of a powerful background mediated by technology is a possible variation in the brain structure, accordingly, it is stated that young people think and process information necessarily in different ways compared to older generations (Prensky, 2001a; Prensky, 2001b). Prensky explains that digital natives are used to receive information faster, making parallel activities 
or multi-tasking, understanding better graphics than text and showing preference for games than "serious" work (2001a, p.1). Consequently, the author proposes that people of this generation are native speakers of the language of computers, games and internet.

The author proposed another important concept Digital Immigrants. He stated that it is composed by people who were born before 1980. According to him digital immigrants may learn to use new technologies but will still be in some way located within the past, unable to fully understand the natives (2001a, p. 2).

As we can observe there is a determinant factor of distinction for Prensky that is the age. Nevertheless there is very little evidence that young people are radically different in the ways they use and process information (Bennet et al., 2008). For that reason there is a growing academic research questioning the validity of the generational interpretation of the digital native concept. Supporting the duality among native / immigrant tend to assign characteristics as specific learning style, amount and type of technology use, or set of learning preferences to an entire generation, and suggest that all young people are expert with technology (Bennet et al., 2008). Nonetheless, while the proportion of young people who use the Internet and other new technologies is higher than the older population (e.g. Cheong, 2008) there is amount of differences in how and why young people use these new technologies and how effectively they use them (e.g. DiMaggio and Hargittai, 2001; Facer \& Furlong 2001; Hargittai and Hinnart, 2008; Livingstone \& Helsper, 2007). Indeed, some of these authors highlight some arguments related to the complexity of determining the characteristics of a digital native without having in mind at least three elements: age, experience and breadth of use.

Therefore, there is a reality that goes beyond the discussion among being native or immigrant, the profound changes that education is facing due to the new characteristics that students have. The term digital native, net generation and other catchy terms are just a way to refer to deep changes required on the educational context.

\section{Materials and methods}

\section{Research Design}

This stage of the study followed the principles of qualitative and naturalistic research for characterizing digital competences on students. Qualitative research is a situated activity that locates the observer in the world. It consists of a set of interpretive, material practices that makes the world visible. These practices transform the world. They turn the world into a series of representations, including field notes, interviews, conversations, photographs, recordings, and memos to the self. At this level, qualitative research involves an interpretive, naturalistic approach to the world. This means that qualitative researchers study things in their natural settings, attempting to make sense of, or to interpret, phenomena in terms of the meanings people bring to them. (Denzin \& Lincoln, 2005, p. 3)

The purpose was to provide a framework that describes and analyzes the way students interact with digital tools from an instrumental stage to a critical perspective that allow them to recognize themselves as digital natives.

In that context a descriptive case study was conducted, it defines a situation by providing measures of the event or activity. Usually, descriptive research designs are structured based on characteristics described in the research question. The hypotheses, derived from theory, serve to guide the process and provide a list of what needs to be measured (Hair, Babin, Money \& Samouel, 2003). The objective of descriptive research is to portray an accurate profile of persons, events or situations. It is necessary to have a clear picture on the phenomena on which researchers wish to collect data prior to collection process (Saunders, Lewis \& Thronhill, 2003). 


\section{Participants}

In the data collection instrument there were included the following questions to characterize the population:

Genre; social status; age; academic level: primary/ secondary/ technical/ professional/ post graduate; and work area. Besides it was consulted which of the following tools they have access to and how long they interact with them: computer, smartphone, mp3, IPod, videogames console, digital camera and television.

Based on the information collected it was possible to identify that the participants of the study were 67 students from fourth to eighth semester, chosen at random, 55 female and 12 female students with an average age of 22 years from urban areas and 2nd and 3rd social status. The majority of them are in a technical academic level $67 \%$, and they work in client service $45 \%$, education $25 \%$ and others $30 \%$. In addition, the most common technological tools among them are the television, computer and the smartphone, followed by the videogames console, digital camera and music devices. Finally, the majority of them expressed they used the digital tools for more than 4 hours per day $83 \%$ or at least 3 hours per day $17 \%$.

\section{Data Collection Instruments}

For characterizing digital competences among populations at large, a variety of techniques can be employed. For this first stage of the project we decided to use online surveys that allow us to collect perceptions of participants' about their digital competences. In the survey designed participants were presented with a list of skills and were asked to evaluate how well they perform those skills. Among the advantages of using self-report questionnaires for data collection we can highlight the possibility to present a large number of questions on a wide range of skills in a short time, simple scoring, fast processing, and cost effectiveness (Kuhlemeier \& Hemker, 2007).

The survey was divided in three parts having in mind Area (2010) proposal the dimensions of learning related to digital competences development.

\begin{tabular}{|ll|}
\hline & Multi-literacy dimensions \\
\hline Instrumental Dimension & Access and search information. \\
\hline Cognitive Dimension & Transform information into knowledge. \\
\hline Communicative Dimension & $\begin{array}{l}\text { Express and share information; communicate } \\
\text { with others. }\end{array}$ \\
\hline Axiological Dimension & Use the information democratically and ethically. \\
\hline
\end{tabular}

Figure 2. Learning dimensions for digital competence development. Adapted from Area (2010, p. 46). 
Based on this proposal the instrument was created with twenty questions, nine for the instrumental dimension that is defined as the basic skills required to manage technological tools and searching of information; six for the socio communicative dimension that aims to characterize students' interactions with social networks and abilities to select and validate information; and finally, five questions for the axiological dimension that is directed to illustrate social and ethical values and attitudes in front of technology.

The questions below belong to the instrument mentioned:

\section{Dimensión instrumental}

1. ¿Reconoce la diferencia entre un Smartphone y una Tablet?

2. ¿Utiliza las aplicaciones (software) de sus dispositivos de manera eficiente?

3. ¿Utiliza aplicaciones para organizar información?

4. ¿Configura herramientas de software para llevar control de actividades y proyectos?

5. ¿Aplica las herramientas tecnológicas para solucionar problemas de la vida diaria?

6. ¿Puede hacer instalación de aplicaciones en sus dispositivos?

7. ¿Puede hacer conexiones entre los diferentes dispositivos electrónicos?

8. ¿Puede hacer cambios en la configuración del sistema operativo de sus dispositivos?

9. ¿Utiliza sus dispositivos para jugar en videojuegos?

Dimensión sociocomunicativa

10. ¿Usa sus dispositivos para interactuar en tiempo real con otras personas? a. ¿Utiliza la mensajería instantánea (correo electrónico, chat, mensajes de texto, WhatsApp o redes sociales como Ning, Facebook, Twitter, Hi5, Myspace, Tuenti, etc.) para comunicarse con otras personas?

b. ¿Interactúa con otras personas a través de videollamadas o video chat (Skype, Facebook, Google Hangouts, etc.)?

c. ¿Se comunica mediante llamadas por internet mediante Line, WhatsApp, Tango u otras aplicaciones?

11. ¿Qué tipo de videojuegos prefiere?

a. De entretenimiento

b. De deportes

c. Musicales

d. Educativos

e. De agilidad mental

12. ¿Utiliza los medios tecnológicos (computador, tablet, smartphone) para realizar consultas que amplíen sus conocimientos?

a. Usa Wikipedia como fuente de información.

b. Se apoya en los foros de discusión para resolver sus preguntas.

c. Participa proactivamente en entornos virtuales de aprendizaje, redes sociales foros y espacios colaborativos.

d. Visualiza videos de Youtube en donde explican el tema de manera detallada.

e. Lee artículos de revistas especializadas en el tema de consulta.

13. ¿En sus consultas realiza recopilación, reelaboración y reconstrucción de la información en diversos formatos (.ppt, .pptx, .doc, .docx, .pdf, etc.)?

14. ¿Evalúa la validez de las fuentes de información que consulta?

15. ¿Utiliza los medios tecnológicos (computador, tablet, smartphone) en su aprendizaje académico (colegio, universidad)? a. Reconoce aplicaciones disponibles en la red que pueden ayudarle en su aprendizaje académico.

b. Es usuario de plataformas educativas 
(Moodle, Blackboard, etc.).

c. Es usuario de plataformas de cursos virtuales (edX, coursera).

d. Hace uso del software de sus dispositivos para su aprendizaje académico.

e. Colabora en el aprendizaje académico mutuo a través de herramientas digitales

16. ¿Utiliza de las Tecnologías de la información y la comunicación (TIC) en apoyo del pensamiento crítico, la creatividad y la innovación?

\section{Dimensión axiológica}

17. Soy autónomo en la selección crítica de los contenidos e información que busco reconociendo su contexto socio cultural particular.

18. Se reconoce como un sujeto activo $\mathrm{y}$ participativo en la sociedad digital del conocimiento.

19. Gestiona la identidad digital y el grado de privacidad de los datos personales y de la información en Internet.

20. Reconoce los riesgos de la gestión inadecuada de la seguridad de los datos que provee en la red.

\section{Data Analysis and Interpretation}

The data analysis and interpretation process involved descriptive statistical analysis based on the three categories proposed from the theory: Instrumental Dimension, Socio Communicative Dimension and Axiological Dimension. After collecting and analyzing data from the survey it was possible to observe a range of students' interactions with technological platforms and applications. Finally we could map students' digital competences in relation to the "digital native" denomination.

For the sample analysis first it was determined for each question the amount of people who answer positively or negatively, establishing a maximum of 20 questions answered positively and a minimum of 10 answered negatively.

To follow the data analysis process the questions were grouped in the three dimensions. Questions 1 to 8 and 10 belong to the Instrumental Dimension, question 9 and 11 to 15 to the Socio Communicative Dimension and questions 16 to 20 to the Axiological Dimension. This grouping gave as a total of 9 questions in the first dimension, 6 in the second, and 5 in the last one. To normalize the qualification for the statistical analysis and figures it was presented in a scale of 0 to 5 were the 5 corresponds to the maximum of positive answers for each dimension, 9 in the first one $(9=5), 6$ in the second one $(6=5)$ and five in the last one $(5=5)$. A score of zero to five was assigned by giving a five who gave an affirmative answer in all the questions of each dimension and a zero who did not give any positive response. They were also develop histograms with a unitary range of interval, i.e. the first interval corresponding to qualifications between zero and one, the second to scores between 1 and 2, and so on up to 5. The upper ends of each interval were chosen as class marks. Finally, histograms of relative to each of the dimensions frequencies were developed to show the results.

\section{Results and discussion}

Histograms of relative to each of the dimensions frequencies are shown in graphs 1, 2 and 3. The greater relative frequency in the brand of class 5 was obtained in three dimensions, however, none of the three cases was obtained a relative frequency of $100 \%$, and the largest $51 \%$ corresponds to the social dimension. 

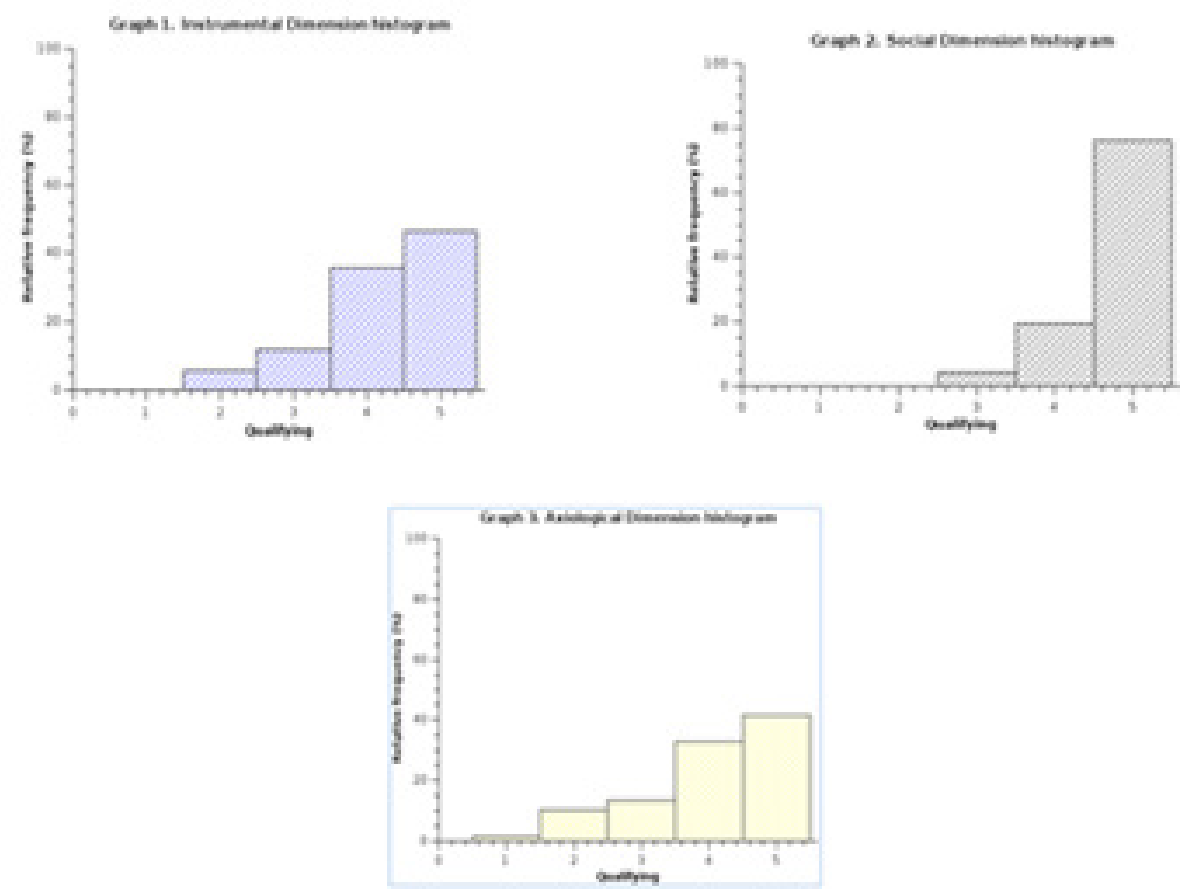

According to the data analyzed we can observe that the participants use technological tools in different context although not all of them know the way those tools work. It is important to highlight that Socio Communicative Dimension received the highest qualifications; this could be related to the particular interest of the participants and also to the fact that social networks includes tools as forums, videos and collaborative gears that allow an easy interaction among the users.

The percentage of respondents who use their devices to play was also established within the instrumental dimension, obtaining 61.2\%. Most used games to entertain themselves and to develop their mental agility, but few use them for educational activities. At this point it is important to reflect about the way education is using the technology to support academic processes. Apparently, there is still a digital divide regarding to access, use, or impact of information and communication technologies (ICT) in the participants of this study, even when the majority of them can access for more than 4 hours a day to the digital tools. Furthermore it is important to note that this preference for entertainment and mental agility games has been taken into account in the development of the "serious game". 


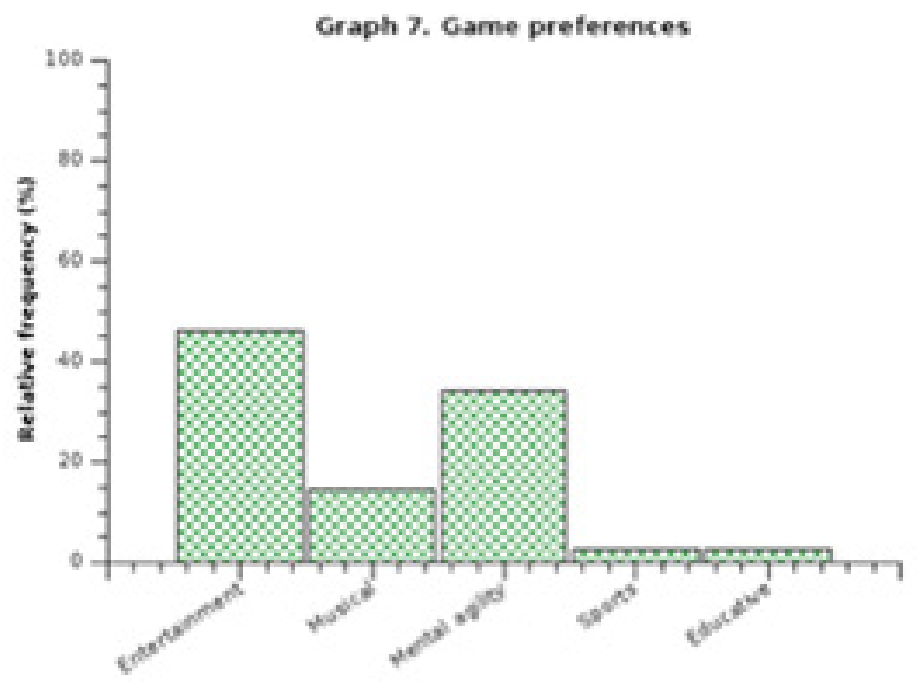

For the Socio Communicative Dimension it is important to mention that there sub questions for characterizing students usage of technological tools in socio communicative situations. Question 9 referred to the use of technological devices for interpersonal communication. We can observe in the figure that $98 \%$ of the participantes use their technological tools to interact in real time with other people through instantaneos messages, $81 \%$ of them use video calls and $79.4 \%$ for online callings. It is important to mention that users can apply their technological tools for one, two or the three options at the same time. The results suggest that participants are more comforable texting than speaking when interacting with other people which is a characteristic mentioned by Prensky in his decription of Digital Natives.

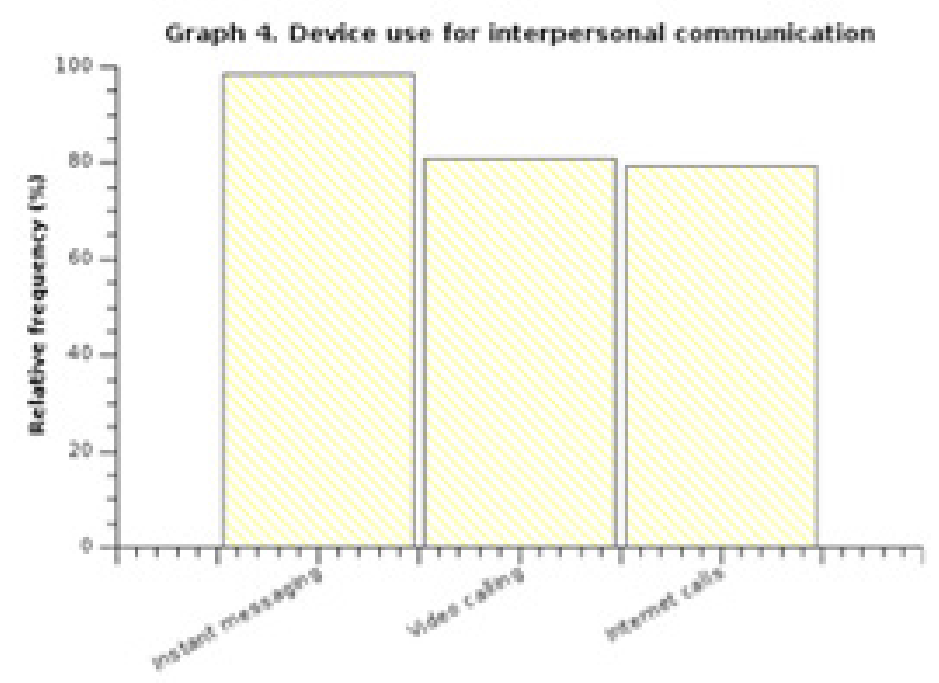


Question 11 inquired participants about the use of technology to search new information. In this figure we can observe that all the participants participante use technological tools to complement their knowlede being youtube the tools they prefer the most with $91 \%$ of users, followed by wikipedia with $62.7 \%$, specialized articles with $58,2 \%$, foros $47.8 \%$ and finally virtual environmnets with $46.3 \%$ of users.

The previous analysis supports Prensky definition related to digital natives having in mind that Prensky (2001) describes the preference of digital natives for graphics and interactive tools to support their learning rather than the ones that are related to academic usage. However there is a disadvantage in the type of information they can collect from nonacademic sources as Wikipedia that is the most frequent resource they access when requiring for information. This data made us reflect about the responsibility and critical point of view participants have in front of the information they access to.

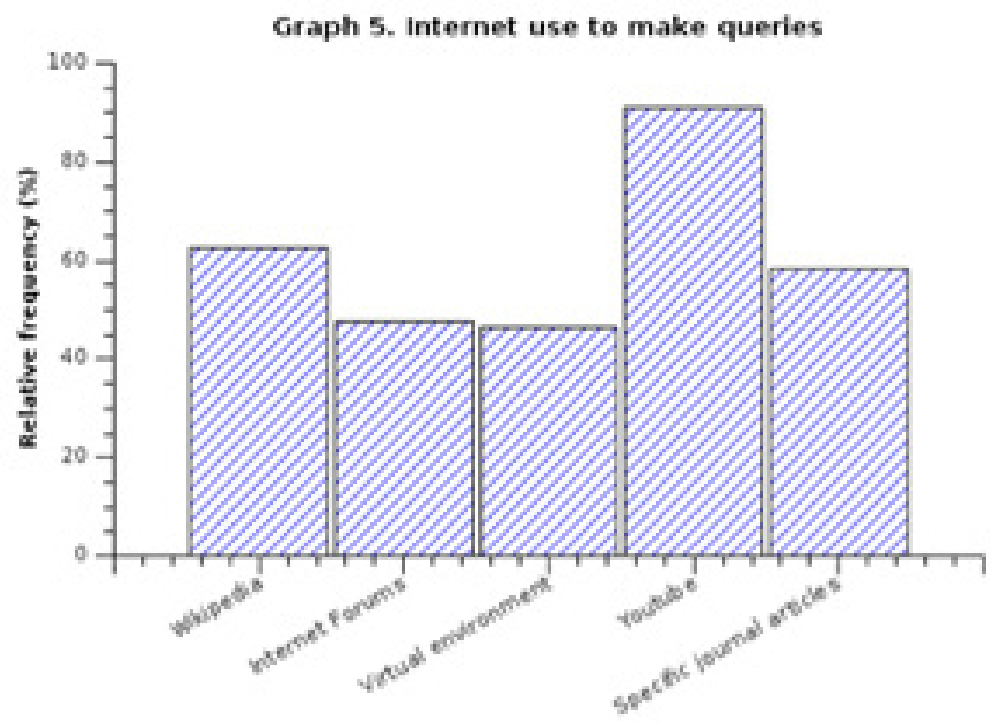

Question 14 reflected about the use of techological sources for learning purposes. This figure show us that the $83 \%$ of the participantes use their technological tool for academic learning throug apps available in the net, $77.3 \%$ of them use software they can download in their devices and $68.2 \%$ participate in colaborative learning networks. Finally, related to this dimension we can observe that 47 and $27.3 \%$ of the users access to educative platforms and virtual courses. The preference for apps instead of educative platforms show us the necessity of using them to enhace students skills and improve educative platforms to offer interactive and meaningful experience for users. 


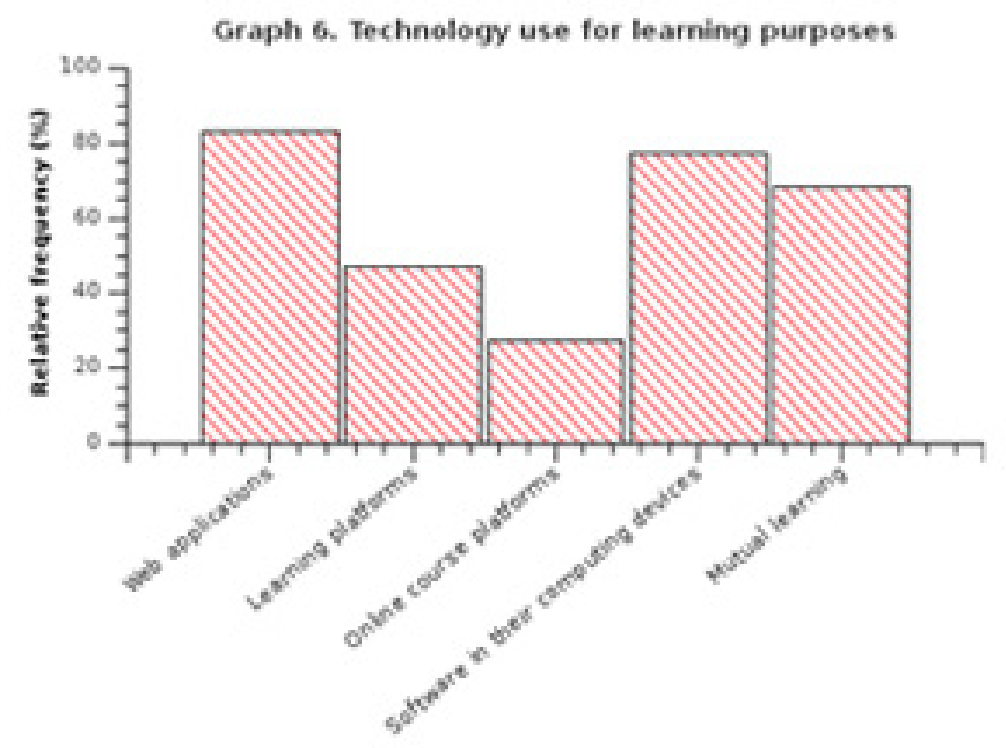

Individuals use the internet to carry out various activities depending on their level of digital skills as well as their socioeconomic background. This indicator has its limitations. The percentage of individuals that undertake certain activities depends largely on the age group to which they belong as well as on their educational level. Moreover, it is obvious that senior people use ICT to perform types of activities that are substantially different from the ones performed by younger individuals.

Finally, we can refer to the axiological dimension in relation to the socio communicative dimension in the validation of information process that participants make for academic purposes. Although most of them answer affirmatively to the responsibility they have as digital citizenships, we can observe in graph 5 the main sources of information for them are YouTube and Wikipedia that are not validating their knowledge. It is important to mention that a short definition of digital citizenship was given to the students in the instrument for them to answer the questions related to this dimension.

Personal attitudes refer to the manner in which individuals use ICT. Digital competence encompasses the ability to select information and to analyze it creatively, critically, constructively, confidently and responsibly. While direct measures of the personal attitudes required to be digitally competent are not available, some can be proxied.

In particular, responsible use is proxied by the following user statement: "I cannot manage very well my digital identity". On average, only $23 \%$ of individuals in the study could understand very well the meaning of digital citizenship, while a higher percentage protect their privacy and know about security in websites.

\section{Conclusions}

In general terms, we can say from the data analyzed that participants of this study present particular characteristics related to the constant use of technological tools to support different processes, for that reason it is important to improve in the institutions, teaching and learning practices supported by academic, interactive and interesting sources.

Related to the Instrumental Dimension we can conclude that not all the participants know the uses of their devices even when they use them constantly. Nevertheless, majority of them expressed preference for visual, 
interactive and audio visual contents rather than readings or platforms that not include that kind of elements. However, some of the participants also mentioned the importance of having access to academic material for supporting their learning process. As we already state in the literature review, digital natives are used to receive information faster, making parallel activities or multi-tasking, understanding better graphics than text and showing preference for games than "serious" work (Prensky, 2001a, p.1).

According to the data collected the Socio Communicative Dimension is the one that had been more explored by the participants; they interact with other people on line preferring texting than chatting and using social networks to construct cooperative knowledge. They participate in different social groups and platforms showing a preference for validating the information they get in a collaborative way rather than through more academic sources. This characteristics are related with the proposal of the Assessment and Teaching of 21 st Century Skills project (ATC21, 2009), that defined the ways of working as communication and collaboration or teamwork.

Finally, in relation to the Axiological Dimension it was observed that there is not a deep comprehension of the concept of digital citizenship among the participants of this study. This can be related to the fact that they are not totally aware of their responsibilities when accessing, sharing and even creating digital contents. According to UNESCO (2010), the International Society for Technology in Education (ISTE, 2007), and the Assessment and Teaching of 21st Century Skills project (ATC21, 2009), critical thinking, problem solving, decision making; digital citizenship, are key skills for the digital competence development.

This study compiled digital natives'perceptions on competences in a specific context. The outputs that are presented here are the result of a systematic consultation, research and analysis process. However, this remains a conceptual framework, as it has never been tested in other contexts. A subsequent step for this proposal would be to test the framework constructed in different settings to expand the analysis and compare the results. The proposal made here can be seen as a start in conceptions and interpretations of digital competence and social practices using digital media, which over time will have to become more elaborated and specified.

\section{References}

Ala-Mutka, K. (2011). Mapping Digital Competence: Towards a Conceptual Understanding. Sevilla: Institute for Prospective Technological Studies. Retrieved from http://ftp.jrc.es/EURdoc/JRC67075 TN.pdf

Ala-Mutka, K., Punie, Y. \& Redecker, C. (2008). Digital Competence for Lifelong Learning. Seville: IPTS.

Retrieved from ftp://ftp.jrc.es/pub/EURdoc/ JRC48708.TN.pdf

Area, M. (2010). Tecnologías digitales, multialfabetización y bibliotecas en la escuela del siglo XXI. Boletín de la Asociación Andaluza de Bibliotecarios, ${ }^{\circ}$ 98-99, EneroJunio 2010, pp. 39-52. Retrieved from http:// www.edu.xunta.es/portal/sites/web/files/a area_multialfabetizacion_be.pdf

ATC21. Draft White Papers (2009). The Assessment and Teaching of 21st Century Skills project. Unpublished manuscript.

Bennett, S., Maton, K., \& Kervin, L. (2008). The 'digital natives' debate: A critical review of the evidence. British Journal of Educational Technology, p. 775-786.

Cheong, P. (2008). The Young and the techless? Investigating Internet use and problem - solving behaviors of young adults in Singapore. New Media and Society, p. 771791. 
Cinque, M. (2014). Stop and Rewind. University Students Reflecting on their Digital Practices. Official Journal of SIREM. Italian Society for Research on Education and Media, p. $87-100$.

Denzin, N., \& Lincoln, Y. (2011). Handbook of qualitative research. Fourth Edition. Thousand Oaks, CA: Sage.

DiMaggio, P., \& Hargittai, E. (2001). From the digital divide to digital inequality: studying Internet use as penetration increases. Working Paper Series (15) Princeton University, Center for Arts and Cultural Policy Studies. Retrieved from http://www.princeton.edu/ culturalpolicy/workpap/WP 1 5\%20-\%20 DiMaggio+Hargittai.pdf

Eshet-Alkalai, Y. (2004). Digital Literacy: A conceptual framework for survival skills in the digital era. Journal of Educational Multimedia and Hypermedia, p. 93-106.

Eshet-Alkali, Y., \& Amichai-Hamburger, Y. (2004). Experiments in digital literacy. Cyber Psychology \& Behavior, p. 421-429.

Erstad, O. (2010). Educating the Digital Generation. Nordic Journal of Digital Literacy, p. 56-70.

European Parliament and the Council. (2006). Recommendation of the European Parliament and of the Council of 18 December 2006 on key competences for lifelong learning. Official Journal of the European Union, L394/310.

Facer, K., and Furlong, R. (2001). Beyond the myth of the 'Cyberkid': Young people at the Margins of the Information revolution. Journal of Youth Studies, p. 451-469.

Ferrari, A (2013). DIGCOMP: A Framework for Developing and Understanding Digital Competence in Europe. European Commission Joint Research Centre Institute for Prospective Technological Studies.

Gilster, P. (1997). Digital literacy. New York:
Wiley.

Grün, G; Tritscher-Archan, S; Weiß, S (2009). Guidelines for the Description of Learning Outcomes. Retrieved from http://ibw4.mservices.at/zoom/pdf/wp2/Guidelines_EN_ final_2.pdf

Hair, J., Babin, B., Money, A., \& Samouel, P. (2003). Essentials of business research methods. Hoboken, NJ: Wiley.

Hargittai, E., \& Hinnart, A. (2008). Digital Inequality: differences in young adults' use of the Internet, Communication Research, $\mathrm{p}$. 602-621.

ISTE (2007). Profiles for Technology (ICT) Literate Students. Washington, D.C.: International Society for Technology in Education.

Jones-Kavalier, B., \& Flannigan, S. (2008). Connecting the digital dots: Literacy of the 21st century. Teacher Librarian, p. 13-16.

Jung, J., Qiu, J., \& Kim, Y. (2001). Internet Connectedness and Inequality: Beyond the Divide. Communication Research, p. 507-35. Kling, R. (2000). Learning about information technologies and social change. The contribution of social informatics. The Information Society, p. 217- 232.

Livingstone, S. and Helsper, E. (2007) Gradations in Digital Inclusion: Children, Young People and the Digital Divide. New Media \& Society. 9, 671-696.

Merchant, G. (2007). Writing the future in the digital age. Literacy, p. 118-128.

Mossberger, K., Tolbert, C., \& Stansbury, M. (2003). Virtual Inequality: Beyond the Digital Divide. Washington, DC: Georgetown University Press.

OECD (2005). The OECD Program Definition and Selection of Competencies (2005). The definition and selection of key competencies. Executive summary. Retrieved from http:// 
www.oecd.org/pisa/35070367.pdf

Prensky, M. (2001a) Digital Natives, Digital Immigrants: Part 1. On the Horizon, p. 1 - 6.

. (2001b) Digital Natives, Digital Immigrants Part 2: Do they really think differently? On the Horizon, p. $1-6$.

Punie, Y., \& Cabrera, M. (2006). The Future of ICT and Learning in the Knowledge Society. Luxembourg: European Commission.

Saunders, M; Lewis, P; \& Thronhill, A (2003). Research methods for business students. Third Edition. Pearson Education Limited, England.

Sefton-Green, J; Nixon, H; \& Erstad, O. (2009). Reviewing approaches and perspectives on "Digital literacy". Pedagogies, p. 107-125.

University of Victoria (2011). What makes up a competency? Retrieved from https:// www.uvic.ca/coopandcareer/assets/docs/ corecompetencies/What_makes_up_a_ competency_infosheet.pdf
Van Deursen, A. (2010). Internet Skills. Vital assets in an information society. University of Twente. Retrieved from http://doc.utwente. $\mathrm{nl} / 75133 /$

Van Dijk, J. (2005). The deepening divide. Inequality in the information society. London: Sage Publications.

UNESCO (2008). Competency Standards Modules. ICT Competency Standards for Teachers. United Nations Educational, Scientific and Cultural Organisation. Retrieved from http://unesdoc.unesco.org/ images/0015/001562/156207e.pdf

Warschauer, M. (2003). Technology and Social inclusion: Rethinking the Digital Divide. Cambridge, MA: The MIT Press.

Zyda, M (2005). From visual simulation to virtual reality to games. Computer, 38(9), 2532. 